\title{
APLICAÇÃO DIFERENCIADA DAS ASTREINTES NO DIREITO AMBIENTAL PARA GARANTIR A EFETIVIDADE DA SUA PROTEÇÃO ${ }^{1}$
}

\section{DIFFERENTIATED APPLICATION OF ASTREINTES ON ENVIRONMENTAL LAW FOR GUARANTEE THE EFFECTIVENESS OF YOUR PROTECTION}

\author{
Magno Federici Gomes ${ }^{2}$ \\ Thiago Loures Machado Moura Monteiro ${ }^{3}$
}

\section{RESUMO}

No presente artigo foram discutidos o instituto e a função da multa diária como um instrumento de efetivação da tutela específica das obrigações no Direito ambiental. O problema reside nas consequências de se estipular um limite prévio, o chamado teto pecuniário, para a multa diária das obrigações de fazer, inibir e entregar na tutela processual diferenciada ambiental. A metodologia de pesquisa utilizada foi a teórico documental, com técnica bibliográfica de cunho qualitativo. A conclusão aponta para a impossibilidade de se fixar um teto para tais multas diárias, em razão das especificidades do Direito ambiental.

Palavras-chave: Multa diária; Limite prévio; Direito ambiental; Tutela específica das obrigações.

\begin{abstract}
On the present article, is discussed an institute and function of the daily fine as an instrument for effecting specific guardianship of obligations in environmental law. The problem resides in consequences of a previous calculation, the so-called pecuniary roof, of the daily fine of the obligations to make, inhibit and deliver in procedural guardianship environmental differentiated. The research methodology used was the documentary theorist, with a qualitative bibliographical technique. The conclusion points to the impossibility of setting a roof for such daily fines, given the specificities of environmental law.
\end{abstract}

Keywords: Daily fine; Previous limit; Environmental law; Specific guardianship of obligations.

\footnotetext{
${ }^{2}$ Pós-doutor em Direito Público pela Universidade Nova de Lisboa (Portugal). Professor do Mestrado Acadêmico em Direito Ambiental e Sustentabilidade na Escola Superior Dom Helder Câmara e na Pontifícia Universidade Católica - PUC/MG, Minas Gerais (Brasil). E-mail: magnofederici@gmail.com

${ }^{3}$ Mestrando em Direito Ambiental e Sustentabilidade na Escola Superior Dom Helder Câmara. Pós-graduado em Direito do Trabalho e processo do Trabalho pela universidade FUMEC. Advogado.

E-mail: thiagoloures.adv@gmail.com
} 


\section{INTRODUÇÃO}

O meio ambiente é interligado, isto significa dizer que um dano causado em um determinado trecho de um rio, afetará outras áreas alcançadas pelo mesmo, de forma direta e indireta. Assim, promover a reparação de um dano ao meio ambiente se mostra tarefa árdua e onerosa. De modo que uma simples ordem judicial, com a obrigação de reparar o meio ambiente, pode representar algo inviável ao poluidor, que preferirá arcar com uma indenização substitutiva em dinheiro, alegando argumentos de razoabilidade e proporcionalidade, no momento da quantificação dos danos.

Dessa maneira, a multa diária surge não como um substituto da obrigação de reparar o meio ambiente degradado, mas sim como uma forma de dar efetividade a decisão que ordena tal reparação. E em razão de ter uma finalidade diversa da simples multa com caráter sancionador ou compensatório, o instituto da multa diária em matéria ambiental deve ser analisado a parte, discutido para além do simples limite da própria multa diária, mas principalmente sobre se deve existir um teto prévio para ela.

Seguinte ao problema principal da presente pesquisa, sobre a existência deste teto prévio nas multas diárias ambientais, é vital responder outros problemas específicos para alcançar a resposta central, como quais as consequências de se estipular o teto prévio, no âmbito da efetividade jurisdicional. E ainda as peculiaridades do necessário alcance efetivo da tutela diferenciada ambiental, pois precisa alcançar a proteção das gerações futuras.

Com isso, a justificativa da presente pesquisa se dá pela necessidade de se compreender o instituto da multa diária como a parte de um todo, que é a tutela diferenciada ambiental, em seu caráter transgeracional.

A metodologia utilizada no presente artigo é a teórico documental, com técnica bibliográfica de cunho qualitativo, aliada a análise de jurisprudência, julgados e doutrina. Para tanto, Dworkin (2002), em seu método interpretativo do direito, é utilizado como marco teórico da pesquisa, na concepção de construção jurídica própria para o caso concreto, que nesta pesquisa é a tutela diferenciada ambiental.

Para compreensão da tutela diferenciada na jurisdição civil coletiva, no primeiro capítulo serão apresentados apontamentos sobre a responsabilidade civil em matéria ambiental. Ato seguinte, para possibilitar a instrumentalização da tutela diferenciada, serão 
abordados cinco princípios ambientais aplicáveis ao presente estudo, ou seja, a análise da multa diária no processo civil ambiental.

Antes de trabalhar a multa diária em matéria ambiental, será apresentado o instituto da multa diária lato sensu, envolvendo suas características e finalidades. Após, adentrar-se-á na aplicação da multa diária, também chamadas astreintes, no Direito ambiental. Depois, será feito um recorte para a jurisdição civil coletiva, onde reside a tutela diferenciada ambiental.

No enfoque da multa diária na jurisdição civil coletiva, serão abordados os pontos em comum e peculiares com o direito processual individual, analisando desde o quantum a ser fixado, até o ponto chave do presente estudo, que é a discussão sobre a existência de um teto prévio para a multa diária no contexto da tutela diferenciada ambiental.

\section{RESPONSABILIDADES CIVIL AMBIENTAL}

Em Direito ambiental, aplica-se a teoria objetiva para responsabilidade civil, ou seja, não depende do elemento subjetivo culpa para caracterizar a responsabilidade, e consequentemente o dever de reparar/indenizar.

Tal responsabilidade objetiva já tinha previsão legal antes mesmo da Constituição da República de 1988 (CR/88), sendo disposta expressamente na Lei $n^{\circ}$ 6.938/1981, em seu art. $14, \S 1^{\circ}$, sendo que tal dispositivo foi recepcionado pela CR/88, como ensina Fiorillo (2008):

\footnotetext{
O direito ambiental, atento a essas modificações e considerando a importância dos bens tutelados, adota a responsabilidade civil objetiva. Vale frisar que, anteriormente à Constituição Federal de 1988, a Lei da Política Nacional do Meio Ambiente (Lei n. 6.938/81) já previa a responsabilidade objetiva do poluidor no seu art. $14, \S 1^{\circ}$. Com a promulgação da Lei Maior tal norma infraconstitucional foi recepcionada, tendo como fundamento de validade o art. $225, \S 3^{\circ}$, porquanto este não estabeleceu qualquer critério ou elemento vinculado à culpa como determinante para o dever de reparar o dano causado ao meio ambiente. Consagrou-se, portanto, a responsabilidade objetiva em relação aos danos ambientais (FIORILLO, 2008, p. 39).
}

Uma vez definida a responsabilidade civil ambiental, passa-se à discussão sobre qual teoria do risco deve-se adotar. Tal discussão é de extrema relevância, pois a partir daí é que será possível, por exemplo, afirmar quais excludentes de responsabilidade poderiam ser aceitas em matéria ambiental.

Dentre as teorias do risco, destacam-se quatro, que são: a teoria do risco proveito, do risco criado, do risco administrativo, e do risco integral. Para Vianna (2009, p. 100-101), as 
três primeiras apresentam em comum o fato de não afastarem a possibilidade de excludentes de responsabilidade civil, como caso fortuito, força maior, culpa exclusiva de terceiro e até mesmo a cláusula de não indenizar.

O Brasil, em se tratando de Direito ambiental, adota a teoria do risco integral, que não admite as excludentes de responsabilidade acima citadas. É importante destacar que tal opção não está positivada no ordenamento jurídico de forma expressa, mas é uma opção jurisprudencial, seguida de forma majoritária.

Ressalte-se que o nexo causal se mantém como requisito na teoria do risco integral, sendo que em algumas situações excepcionais admite-se a inversão do ônus de prova. Esta opção pela rigidez nas regras de responsabilidade civil ambiental é um reflexo do mandamento constitucional, de ser um dever de todos a preservação do meio ambiente equilibrado, para a presente e futuras gerações. Logo, já destaca-se que o ordenamento jurídico brasileiro compreende ser necessário conferir um tratamento diferenciado para a tutela ambiental.

\section{PRINCÍPIOS APLICÁVEIS}

Uma vez compreendida a dinâmica da responsabilidade civil ambiental, é essencial abordar as diretrizes de aplicação do Direito ambiental, que são dados pelos seus princípios.

Tal noção de princípios como diretrizes da aplicação do Direito, é extraída dos ensinamentos de Dworkin (2002), que explica a diferença entre regras e princípios, partindo de diferenciar quanto à natureza jurídica, indicando primeiro o que seria a natureza das regras:

\footnotetext{
A diferença entre princípios jurídicos e regras jurídicas é de natureza lógica. Os dois conjuntos de padrões apontam para decisões particulares acerca da obrigação jurídica em circunstâncias específicas, mas distinguem-se quanto à natureza da orientação que oferecem. As regras são aplicáveis à maneira do tudo-ou-nada. Dados os fatos que uma regra estipula, então a regra é válida, e neste caso a resposta que ela fornece deve ser aceita, ou não é válida, e neste caso em nada contribui para a decisão (DWORKIN, 2002, p. 39).
}

Por outro lado, ao explicar a natureza dos princípios, Dworkin (2002) se distancia da ideia do tudo ou nada, transcrito acima para as regras, reconhecendo que se deve compreender o princípio de maneira especial: "tudo o que podemos dizer, ao afirmarmos que um princípio particular é um princípio do nosso direito, é que ele, se for relevante, deve ser levado em 
conta pelas autoridades públicas, como [se fosse] uma razão que inclina numa ou noutra direção" (DWORKIN, 2002, p. 42).

Não existe um número fechado de princípios sobre Direito ambiental, como bem aponta Sampaio (2003, p. 52-53), existe uma variação enorme na doutrina ao definir quantos e quais seriam os princípios envolvendo o Direito ambiental.

Como método de interpretação de princípios, será utilizado o ensinamento de Dworkin (2002), ao considerar os mesmos além da noção de peso, e partindo de uma analise de coexistência harmônica, como explica Costa (2010): "Dworkin não entende os princípios como dimensão de 'peso', mas como um critério de prevalência do bom senso. Portanto, não existe colisão de princípios, como preceituado por Alexy, mas sim uma concorrência que deve ser dosada" (COSTA, 2010, p. 33).

E com base nessa dimensão de coexistência entre os princípios, Dworkin (2002) busca a efetividade, por meio da análise caso a caso, para construção e reconstrução do direito, de modo cíclico e evolutivo, como explicam França e Vilela (2014):

\begin{abstract}
O ativismo público do citado autor era coerente com a visão de que o direito não se reduz a um conjunto de normas codificadas ou a decisões de juízes, mas é um conjunto de práticas sociais constitutivas de uma comunidade de princípios. Para Dworkin, se o direito desempenha função social, em geral, de fundamento da obediência política, e o que fundamenta a obediência não deve ser a reverência cega à autoridade, mas a avaliação de que só deve obedecer a uma estrutura de decisões fundada sobre princípios, o direito deve ser continuamente reconstruído, em cada decisão, em cada caso, para que se torne cada vez mais igualitário (FRANÇA; VILELA, 2014, p. 125).
\end{abstract}

Logo, sem exclusão ou limitação, apresentam-se cinco princípios de suma importância para compressão do tema em estudo, no sentido de reafirmar a necessária tutela diferenciada no âmbito ambiental, que são: prevenção, precaução, razoabilidade, proporcionalidade e desenvolvimento sustentável.

\title{
3.1 Prevenção e precaução
}

Apesar dos princípios da prevenção e precaução terem atuação muito próxima na defesa da preservação do meio ambiente equilibrado diante de riscos, conforme o art. 225 da CR/88, tais princípios são distintos. 
O princípio da precaução é aplicado quando não se tem certeza sobre o dano, como aponta Coelho (2014, p. 61-62), objetivando o combate ao dano em abstrato, quando não se tem certeza científica sobre o dano que poderá ou será causado com determinada ação.

Contudo, o princípio da precaução como todo princípio, não pode ser interpretado de forma ilimitada, pois não é o único princípio existente no ordenamento jurídico. Do contrário, não seria possível conceder autorização ou licença para nenhum estabelecimento ou empreendimento pelo simples fato de que sempre vai existir um risco não conhecido.

Bechara (2009, p. 123) esclarece que para aplicação do princípio da precaução, deve haver risco potencial, ou seja, um indício razoável da possibilidade de dano. Neste sentido, a autora (2009) afirma que existe o risco tolerável, em que ainda assim, pelo contexto geral, deve-se permitir a atividade, e o risco intolerável, quando se aplica o princípio da precaução para negar autorização ou licença para a atividade ou empreendimento potencialmente danoso ao meio ambiente, mesmo sem uma certeza científica de sua existência ou alcance.

Já o princípio da prevenção se aplica quando existe uma certeza científica do dano que pode ser causado. Importante ressaltar que o que hoje é desconhecido e passível de aplicação do princípio da precaução, no futuro provavelmente será conhecido, e então passível da aplicação do princípio da prevenção. De modo que os dois princípios tem o dever eficácia e eficiência, para garantir a preservação do meio ambiente equilibrado.

Nesta linha de raciocínio, Albergaria (2009) destaca a mutabilidade da situação, a partir da Revolução Industrial:

\footnotetext{
No início da revolução industrial, quando Sir Watson inventou a máquina a vapor, não se poderia prever o que aconteceria com o ar que saia pelas chaminés, nem a possibilidade de grandes vazamentos de óleos no mar, o efeito estufa, muito menos que a vaca iria ficar louca ao tornar-se canibal, como ainda não se sabe qual será a consequência dos alimentos transgênicos e dos clones. Indubitavelmente o desenvolvimento industrial teve como "efeito colateral" consequências inesperadas e prejudiciais à Terra.

Hoje, alguns efeitos da atividade humana, principalmente a industrial, são previsíveis, outros não. Há um risco ambiental em toda atividade, em menor ou maior grau, mais ou menos previsível (ALBERGARIA, 2009, p. 115).
}

Consciente desta importância do princípio da prevenção, Machado (2010, p. 94) propõe cinco etapas para viabilizar a aplicação do referido princípio, ou seja, para se adquirir conhecimento sobre os riscos ambientais: 
Sem informação organizada e sem pesquisa não há prevenção. Por isso, divido em cinco itens a aplicação do princípio da prevenção: $1^{\circ}$ ) identificação e inventário das espécies animais e vegetais de um território, quanto à conservação da natureza e identificação das fontes contaminantes das águas e do mar, quanto ao controle da poluição; $2^{\circ}$ ) identificação e inventário dos ecossistemas, com a elaboração de um mapa ecológico; $3^{\circ}$ ) planejamentos ambiental e econômico integrados; $4^{\circ}$ ) ordenamento territorial ambiental para a valorização das áreas de acordo com a sua aptidão; e 5º Estudo de Impacto Ambiental (MACHADO, 2010, p. 94).

Neste compasso, os princípios da prevenção e precaução se completam no objetivo em comum, de preservar o meio ambiente, para presentes e futuras gerações.

\title{
3.2 Razoabilidade e proporcionalidade
}

Assim como os princípios da prevenção e precaução, são essenciais para a compreensão da importância em se dar uma tutela diferenciada em se tratando de Direito ambiental os princípios da razoabilidade e proporcionalidade.

Ao tratar da razoabilidade, Ávila (2009, p. 161) trabalha este princípio em três aspectos, sendo relevante para o presente artigo o aspecto de sua aplicação como medida de equivalência, em conformidade com o caso concreto:

\begin{abstract}
A razoabilidade como dever de harmonização do geral com o individual (dever de equidade) atua como instrumento para determinar que as circunstâncias de fato devem ser consideradas com a presunção de estarem dentro da normalidade, ou para expressar que a aplicabilidade da regra geral depende do enquadramento do caso concreto [...] (ÁVILA, 2009, p. 161).
\end{abstract}

Já ao tratar do princípio da proporcionalidade, o mesmo autor (2009) aponta que sua aplicação não pode ser irrestrita, sem observar as circunstâncias do caso concreto, sob pena de servir de pretexto para amenizar infrações, e desproteger o bem jurídico tutelado:

[...] Os meios devem ser adequados para atingir o fim. Mas em que consiste, precisamente, a adequação? Os meios escolhidos devem ser necessários dentre aqueles disponíveis. Mas o que significa ser necessário? As vantagens da utilização do meio devem superar as desvantagens. Mas qual o sentido de vantagens e relativamente ao quê e a quem elas devem ser analisadas? Enfim, os três exames envolvidos na aplicação da proporcionalidade só aparentemente são incontroversos. Sua investigação revela problemas que devem ser esclarecidos, sob pena de a proporcionalidade, que foi concedida para combater a prática de atos arbitrários, funcionar, paradoxalmente, como subterfúgio para a própria prática de tais atos (ÁVILA, 2009, p. 164). 
$\mathrm{Na}$ linha do raciocínio exposto, de aplicabilidade do princípio da proporcionalidade considerando os parâmetros do caso concreto, Vianna (2009, p. 74), faz uma importante ressalva, sobre o limite do poder discricionário do julgador:

Esse juízo de ponderação de bens e princípios jurídicos, contudo, não deve ser exercido de maneira subjetiva, aleatória ou arbitraria. Deve, ao contrario, se consoar com os ditames e valores previstos na Constituição Federal, a qual é fonte, razão e fundamento das demais normas jurídicas e mesmo do próprio ordenamento jurídico, conferindo-lhe unidade e coerência (VIANNA, 2009, p. 74).

Dessa feita, denota-se que os princípios da razoabilidade e proporcionalidade, apesar de serem essenciais na aplicabilidade do Direito, devem ser aplicados considerando todo o enredo de um caso concreto, a luz da CR/88, configurando em erro grosseiro qualquer tentativa de padronizar a aplicabilidade dos mesmos.

\subsection{Desenvolvimento sustentável}

O termo "desenvolvimento sustentável” apareceu pela primeira vez em documentos internacionais, no ano de 1987, no Relatório da Comissão Mundial sobre o Meio Ambiente e Desenvolvimento, mas já vinha sendo abordado o tema de buscar um equilíbrio ambiental na esfera do desenvolvimento e progresso imediato desde 1972, no clube de Roma, que resultou no relatório intitulado "Limites do Crescimento" e influenciou diretamente a Conferência Mundial do Meio Ambiente, em Estocolmo, realizada no mesmo ano.

A CR/88 não traz expressamente o termo "desenvolvimento sustentável", mas contempla o mesmo como um mandamento constitucional. O já abordado caput do art. 225 da CR/88 prevê o dever de manutenção de um meio ambiente equilibrado, que já tutela o desenvolvimento sustentável, como a forma de alcançar tal objetivo, sendo que o art. 170 da $\mathrm{CR} / 88$, ao estabelecer os princípios da ordem econômica, relaciona o princípio da livre concorrência (pelo aspecto do desenvolvimento) e o de proteção do meio ambiente (aspecto sustentável).

Neste sentido, Thomé (2014) aponta sobre o reconhecimento do Princípio do Desenvolvimento Sustentável, frente ao art. 170 da CR/88:

Relevante realçar, desde logo, a defesa do meio ambiente (inciso VI do artigo 170 da Constituição de 1988) como princípio da ordem econômica, clara indicação 
constitucional da necessidade de harmonização entre atividade econômica e preservação ambiental (THOMÉ, 2014, p. 149).

Ao partir da premissa de coexistência de princípios e do dever de coerência do ordenamento jurídico, Sampaio (2003, p. 47), defende que o princípio do desenvolvimento sustentável é o prima principium ambiental, ou seja, é a base para qualquer análise sobre a tutela ambiental.

Ao se destacar que a compreensão adequada desse princípio não é de crescimento econômico propriamente dito, pois este pode ou não ser sustentável, já o desenvolvimento, envolve uma perspectiva analítica, apontando não apenas o aspecto econômico, mas sim a coexistência com o respeito ao meio ambiente, no intuito preservacionista, mas garantindo um crescimento pautado na função socioambiental ${ }^{4}$.

\section{FUNÇÃO DA MULTA ESPECÍFICA/REPARATÓRIA ESPECÍFICA}

O instituto da multa, de maneira geral, tem caráter condenatório em razão do descumprimento por ação ou omissão de alguma obrigação, semelhante à multa de trânsito aplicada ao motorista que ultrapassa o limite de velocidade, ou deixa de usar o cinto de segurança.

Já a multa diária, também conhecida por astreintes, tem uma característica própria, qual seja, coagir o multado a cumprir obrigação de fazer ou não fazer em determinado tempo. Neste sentido, através da multa diária é possível ao juiz forçar que a decisão de tutelar um bem jurídico tenha efetividade.

Mesmo tendo como característica principal coagir o multado a realizar o cumprimento da decisão judicial, ela não perde por completo o viés reparatório, na medida em que acaba por indenizar o vencedor da ação pela demora ou atraso no cumprimento de ordem judicial.

Contudo, o caráter reparatório da multa diária é um efeito colateral e não faz parte de sua essência jurídica, posto que o art. 461, § 1º, do CPC/1973, já prevê que a obrigação de cumprir a tutela específica só será convertida em perdas e danos se o autor requerer ou se for impossível a tutela específica ou seu resultado prático equivalente, e, ainda, o $\S 2^{\circ}$ do mesmo dispositivo adverte que a indenização por perdas e danos não afasta a multa. O NCPC/2015,

\footnotetext{
${ }^{4}$ Para aprofundamentos, ver: GARCIA, 2016, p. 133-153.
} 
no art. 500, torna ainda mais claro que indenização por perdas e danos não afasta a multa prevista para compelir o réu ao cumprimento da obrigação.

Logo, no momento em que a multa diária é aplicada, sua função é compelir o multado ao cumprimento de tutela específica, seja obrigação de fazer ou não fazer. Acrescente-se que se a tutela específica for convertida em perdas e danos, a multa ainda será devida pelo caráter reparatório em razão do atraso ao cumprimento de ordem judicial, mas não com o fito de indenizar os prejuízos pelo seu descumprimento, pois para isto serve a indenização por perdas e danos.

E se o valor fixado para multa diária for irrisório ou exorbitante, é possível manejo de recurso para alteração de seu quantum, sendo que o novo valor será devido desde quando era exigível a quantia antiga, pois o novo é o que se mostra o adequado. Neste sentido o STJ tem um precedente que considera os 49 meses de atraso e que a multa diária arbitrada foi em valor reduzido e não conseguiu dar efetividade à decisão, majorando-se a multa para $\mathrm{R} \$$ $7.000,00$ (sete mil reais) diários, devidos desde quando o primeiro valor foi estabelecido 5 .

Cabe destacar que a exigibilidade do pagamento da multa diária dá-se apenas com o trânsito em julgado da decisão que a fixou. Logo, tendo este caráter precário, é razoável compreender que a alteração de seu quantum tenha efeito ex tunc.

\section{APLICABILIDADE DIFERENCIADA DAS ASTREINTES EM DIREITO AMBIENTAL}

\footnotetext{
${ }^{5}$ Leia-se trecho da ementa: “[...] 2. Sendo o descaso do devedor o único obstáculo ao cumprimento da determinação judicial para o qual havia a incidência de multa diária e considerando-se que ainda persiste $o$ descumprimento da ordem, justifica-se a majoração do valor das astreintes. 3. A astreinte deve, em consonância com as peculiaridades de cada caso, ser elevada o suficiente a inibir o devedor - que intenciona descumprir a obrigação - e sensibilizá-lo de que é muito mais vantajoso cumpri-la do que pagar a respectiva pena pecuniária. Por outro lado, não pode o valor da multa implicar enriquecimento injusto do devedor. Precedentes. 4. Na hipótese de se dirigir a devedor de grande capacidade econômica o valor da multa cominatória há de ser naturalmente elevado, para que se torne efetiva a coerção indireta ao cumprimento sem delongas da decisão judicial. Precedentes. 5. Recurso especial provido, para majorar a multa cominatória ao importe de $\mathrm{R} \$ 7.000,00$ (sete mil reais) por dia de descumprimento, sem prejuízo das atualizações legalmente permitidas, adotando como termo inicial, da mesma forma como fez o Tribunal de origem, a data da intimação pessoal do representante legal da recorrida, qual seja, 28 de julho de 2006, de modo que, até o presente momento, resultam aproximadamente 49 meses de descumprimento" (BRASIL. Superior Tribunal de Justiça. Terceira Turma. Recurso Especial 1185260/GO. Rel. Min. Nancy Andrighi, Brasília, 07 out. 2010. Diário de Justiça, Brasília, 11 nov. 2010).
} 
Como já abordado ao analisar os princípios, o Direito ambiental possui uma tutela diferenciada, em razão do comando constitucional, em destaque do art. 225 da CR/88, que lhe confere um caráter transgeracional.

Em outras palavras, para garantir um meio ambiente equilibrado para as presentes e futuras gerações, é essencial conferir um tratamento diferenciado ao Direito ambiental, sob pena de se colocar em risco o futuro de toda a humanidade.

Tal tutela diferenciada não será aplicada sempre que se envolver a temática ambiental, para evitar o uso da hermenêutica a fim de conferir tratamento de direito difuso a direitos individuas. E tal distinção é essencial para a compreensão de quais fontes processuais serão utilizadas na tutela jurisdicional. Neste sentido, explica Fiorillo (2008):

Com isso, falar em devido processo legal em sede direitos coletivos lato sensu é fazer menção à aplicação de um outro plexo de normas e não do tradicional Código de Processo Civil, sob pena de assim violarmos à Constituição, impedindo o efetivo acesso à justiça. Esse outro plexo de normas inova o ordenamento jurídico, instituindo o que passaremos a chamar de jurisdição civil coletiva. Esta é formada basicamente por dois diplomas legais: o Código de Defesa do Consumidor (Lei n. 8.078/90) e a Lei da Ação Civil Pública (Lei n. 7.347/85) (FIORILLO, 2008, p. 366).

E ainda conclui o referido autor (2008):

Dessa forma, a jurisdição civil apresenta-nos dois sistemas de tutela processual: um destinado às lides individuais, cujo instrumento adequado e idôneo é o Código de Processo Civil, e um outro voltado para a tutela coletiva, que se vale da aplicação da Lei da Ação Civil Pública e do Código de Defesa do Consumidor (FIORILLO, 2008, p. 366).

O presente trabalho trata da tutela diferenciada em matéria ambiental, logo no âmbito da jurisdição civil coletiva, aplicando-se $a$ priori a lei de ação civil pública, que autoriza em seu art. 21, a utilização do Código de Defesa do Consumidor (CDC). Tem-se ainda a aplicação subsidiária do CPC, como explica Rodrigues (2010, p. 79-80).

Desse modo, no âmbito da jurisdição civil coletiva, a multa diária em matéria ambiental deve ter um papel diferenciado da multa diária comum, haja vista que se trata de um direito diferenciado, de caráter transgeracional, fundamental, e com especial tutela constitucional.

Rodrigues (2010, p. 73-75) aponta que existem três formas de tutela: a tutela específica, a tutela reparatória in natura, e a tutela reparatória in pecúnia. Para o aludido autor 
(2008), o objetivo da tutela diferenciada ambiental deve ser alcançar a tutela específica, para preservação do bem ambiental, posto que a reparatória in natura nunca conseguirá ser integral e garantir de forma inequívoca a manutenção do equilíbrio ecológico, e a reparação in pecunia é destinada a um fundo federal, criado pela lei de ação civil pública e pela Lei n ${ }^{\circ}$ 9.008/1995, em que não existe uma vinculação de tentar reparar objetivamente o dano que gerou a reparação monetária.

Fiorillo (2008, p. 39) e Silva (2013, p. 349) também defendem que a tutela diferenciada ambiental deve buscar a tutela específica, como prioridade máxima, para garantir a efetividade do direito ao meio ambiente equilibrado, conforme mandamento do art. 225 da $\mathrm{CR} / 88$

Neste cenário, a multa diária, que tem o papel primário de compelir o multado a cumprir a obrigação de fazer ou não fazer, surge como o meio de efetivar a tutela específica, coagindo o multado ao cumprimento célere da ordem judicial.

E no âmbito da jurisdição civil coletiva, a própria lei da ação civil pública estabelece a possibilidade de multa diária, até mesmo de ofício, desde que seja suficiente ou compatível para buscar a tutela específica.

\subsection{Jurisprudência ambiental sobre o quantum e o limite das astreintes}

Já faz parte da rotina nos Tribunais recursos versando sobre o quantum arbitrado para as multas diárias. Na maioria dos casos, o argumento dos multados invoca os princípios da razoabilidade e proporcionalidade, afirmando que a multa é excessiva. E do outro prisma, é comum ao credor questionar o quantum, com base nos mesmos princípios, afirmando que a multa é irrisória e não cumpre a finalidade de compelir o multado ao cumprimento da ordem judicial.

Como exposto anteriormente, o próprio STJ, de acordo com sua Súmula de $n^{\circ} 7$, não admite em recurso especial a análise de reexame de prova, explicitando que não analisa os critérios probantes de fixação da multa diária, mas pode alterar seu valor se constatar que foi irrisória ou exorbitante.

O Tribunal de Justiça de São Paulo (TJSP) possui Câmaras de julgamento reservadas para questões ambientais, e a $1^{\text {a }}$ Câmara Reservada ao Meio Ambiente, decidiu no processo 
de $n^{\circ}$ 0149718-53.2009.8.26.01006 , no bojo de ação civil pública, por reduzir a multa diária de $\mathrm{R} \$ 1.000,00$ (mil reais) pela metade, com base na razoabilidade e no cuidado de a multa diária não se tornar instrumento de confisco. Neste caso, o proprietário de um imóvel rural, alugou o mesmo a uma empresa, que gerou danos no solo, e ao proprietário cumpria o dever de promover estudos do solo, entregar para o órgão ambiental competente, e cumprir as medidas por este indicadas, sendo que o juiz de $1^{\circ}$ estipulou multa diária de $\mathrm{R} \$ 1.000,00$, e o Tribunal reduziu para $\mathrm{R} \$ 500,00$ (quinhentos reais).

A 2a Câmara Reservada ao Meio Ambiente do TJSP decidiu nos autos de $\mathrm{n}^{\mathrm{o}}$ 2041593-87.2014.8.26.0000 ${ }^{7}$, no bojo de ação civil pública, a reformar a decisão de primeiro grau que indeferiu a tutela antecipada e a multa diária, para conceder ambos os pedidos. Tratava-se de um proprietário rural, que realizava intervenções na área de preservação permanente dentro de seu imóvel, deixando, por exemplo, animais bovinos ali pastarem, descumprindo o compromisso assumido de fazer o controle das formigas. Neste caso foi deferida liminar ao Ministério Público, para que o proprietário retirasse os animais, fizesse as cercas para isolar o local e ainda o controle de formigas, no prazo de 30 (trinta) dias, sob pena de multa diária de $\mathrm{R} \$ 1.000,00$ (mil reais) até o limite de $\mathrm{R} \$ 100.000,00$ (cem mil reais).

\subsection{Necessária efetividade da tutela ambiental e a vedação ao enriquecimento sem causa}

Outro argumento recorrente na discussão sobre o quantum da multa diária é a vedação ao enriquecimento sem causa, também chamado de locupletamento, em contraponto a necessária efetividade da tutela ambiental, para se alcançar a tão preconizada tutela específica.

A vedação ao enriquecimento sem causa está positivada no ordenamento jurídico brasileiro, nos arts. 884 a 886 do CC/02, sendo que pela redação do art. 884 do CC/02 ele se configura quando alguém sem justa causa se enriquece à custa de outrem.

Contudo, no caso da multa diária em valor elevado e apesar das considerações anteriores, na jurisdição civil coletiva em matéria ambiental, frisa-se em primeiro plano que,

\footnotetext{
6 SÃO PAULO. Tribunal de Justiça. $1^{\text {a }}$ Câmara Reservada ao Meio Ambiente. Apelação. 014971853.2009.8.26.0100. Rel. Des. João Negrini Filho, São Paulo, 28 fev. 2013. Diário de Justiça, São Paulo, 01 mar. 2013.

${ }^{7}$ SÃO PAULO. Tribunal de Justiça. $2^{\text {a }}$ Câmara Reservada ao Meio Ambiente. Agravo de Instrumento 204159387.2014.8.26.0000. Rel. Des. Paulo Ayrosa, São Paulo, 23 out. 2014. Diário de Justiça, São Paulo, 28 out. 2014.
} 
nos termos do art. 13 da Lei da ACP, o dinheiro da multa não é destinado a outra parte, mas sim a um fundo, a fim ser utilizado para a reconstituição do bem lesado. Logo, quem é 'enriquecido' é a coletividade, para tentar reparar uma lesão à um direito difuso (meio ambiente). E em segundo plano, o fato do valor total de uma multa diária chegar a um montante como R \$ 1.000.000,00 (um milhão de reais), significa que o que fez com que ela chegasse ao valor considerado alto foi o atraso no cumprimento de ordem judicial (enriquecimento com causa). E dizer que tal atraso não configura uma causa justa ao enriquecimento, é um desatino, tendo em vista a importância dos bens tutelados.

Desse modo, se mostra mais adequado o argumento de utilização dos princípios da razoabilidade e proporcionalidade do que propriamente do enriquecimento sem causa, para discussão do quantum a ser fixado para uma multa diária ambiental na jurisdição civil coletiva.

\subsection{Possibilidade do cálculo do custo-benefício em matéria ambiental: limite prévio de valor}

É comum que o julgador, ao estipular uma multa diária, desde pronto estabeleça um limite a ela, por exemplo: multa diária de $\mathrm{R} \$ 300,00$ (trezentos reais) limitada a $\mathrm{R} \$ 30.000,00$ (trinta mil reais). E de fato, pela demora no trâmite dos processos, e considerando que se o demandante não requerer, a tutela específica só será convertida em perdas e danos com a prova da impossibilidade da mesma, se mostra compreensível tal medida para o direito comum.

Entretanto, para tutela específica do Direito ambiental, deve-se analisar os desdobramentos desta medida. Para uma sociedade empresária multinacional que toma suas decisões baseadas na lógica capitalista do custo-benefício, o que significa intimá-la de que se não fizer, ou deixar de fazer, determinada medida será multada em um valor diário, limitado a outra quantia?

Significa possibilitar a esta sociedade empresária calcular se vale a pena descumprir uma ordem judicial. É bem verdade que pela natureza precária da multa diária, se futuramente o juiz perceber que o valor se tornou irrisório ou insuficiente, ele poderá alterar o mesmo. Mas ao falar em matéria ambiental, é possível que dentro do limite máximo de tempo 
estabelecido pela multa diária, torne-se impossível o cumprimento da tutela específica, que é o objetivo da tutela diferenciada ambiental.

Para ilustrar tal situação, imagine que uma empresa recebeu ordem judicial para, em 30 dias, deixar de jogar poluentes, ou efluentes, em um córrego e promover sua recuperação, sob pena de multa diária de $\mathrm{R} \$ 1.000,00$ (mil reais), limitada a $\mathrm{R} \$ 100.000,00$ (cem mil reais). Ou seja, em 100 (cem) dias terá alcançado o limite da multa, com possibilidade provável de estipulação de nova coerção.

Ocorre que despejando poluentes neste córrego, sem um tratamento dos materiais, a economia da empresa é de mais de $\mathrm{R} \$ 200.000,00$ (duzentos mil reais) por mês e a atual recuperação do córrego custará cerca de $\mathrm{R} \$ 400.000,00$ (quatrocentos mil reais), sendo que o empreendedor sabe que se continuar com tal atitude, em poucos meses, será impossível a recuperação do córrego e no momento de se arbitrar a indenização por perdas e danos, ele rogará pelos princípios da razoabilidade, proporcionalidade e ainda o inadequado argumento de enriquecimento sem causa, mantendo seguramente sua confortável margem de lucro.

Ao considerar os efeitos da degradação ambiental, Silva (2013), fala sobre responsabilidade civil ambiental e demonstra uma necessária tutela diferenciada ao bem jurídico ambiental, atacando a limitação a um teto de valor indenizatório:

[...] Demais, os efeitos da poluição geralmente são difusos; procedem, não raro, de reações múltiplas, de muitas fontes. Logo, se a prova é ônus da vítima, esta se encontra em uma situação extremamente desfavorável. A responsabilidade é objetiva integral. Não se pode limitar a indenização a um teto, como às vezes se quer, mediante forma de seguro-poluição (SILVA, 2013, p. 337).

É evidente que o autor (2013) acima citado não estava falando sobre o instituto da multa diária, mas suas palavras são extremamente aproveitáveis no contexto das astreintes, que visam coagir o poluidor a cumprir obrigação de fazer ou não fazer, justamente para tutelar o meio ambiente equilibrado, defendido pelo comemorado doutrinador (2013).

Salientando que para que no contexto da tutela diferenciada ambiental, o julgador tem que tomar uma postura diferenciada, para que a decisão alcance as futuras gerações, como aponta Ramos (2014):

Este juiz deve ser antes de tudo um cidadão livre, e não um escravo da lei como postulavam os juristas de Napoleão. Quer dizer, não deve ser um escravo do projeto monoteísta que só conhece uma solução única para os problemas plurais da sociedade complexa e contemporânea. O juiz intergeracional é alguém capaz de 
abrir a própria mente e reconstruir a racionalidade do conhecimento jurídico que adquiriu nos tempos de sua formação universitária (RAMOS, 2014, p. 307).

Para concretizar a busca pela reparação específica do dano ambiental, por meio da multa diária, os princípios da razoabilidade e proporcionalidade devem ser usados para estipular um prazo razoável para o cumprimento da ordem judicial, sem incidência de multa, mas que se ultrapassado o citado período temporal, a multa seja em valor expressivo e sem limite prévio, sob pena de ser ineficaz e, portanto, inconstitucional por desrespeito aos princípios da eficiência, do desenvolvimento sustentável e da reparação integral do dano, aplicáveis em razão do mandamento do art. 225 da CR/88.

\section{CONSIDERAÇÕES FINAIS}

Inicialmente, foi estudada a peculiar responsabilidade civil em matéria ambiental, esclarecendo sua fundamentação legal e amparo constitucional, bem como sobre a teoria do risco integral, adotada pelo Direito ambiental brasileiro.

Para completar a contextualização na diferenciada tutela ambiental, foram analisados três princípios aplicáveis ao Direito ambiental. Destacou-se a distinção entre prevenção e precaução, apesar de suas proximidades, e ainda foi estudado o princípio do desenvolvimento sustentável como orientador dos demais.

Já sobre a multa diária foi apresentado um conceito amplo do instituto, para então fazer o recorte à multa diária e, posteriormente, apresentar apontamentos das peculiaridades de sua aplicação no Direito ambiental, analisando desde o quantum a ser fixado, perpassando por uma análise jurisprudencial e adentrando ao problema em discussão, que é a (im)possibilidade de se limitar previamente um teto para a multa diária em matéria ambiental.

Quanto aos aspectos sobre a multa diária em processo ambiental de jurisdição civil coletiva, foi ressaltada a aplicação dos princípios abordados e, com base nos postulados normativos da razoabilidade, proporcionalidade e sustentabilidade, concluiu-se que deve ser estipulado um prazo razoável para cumprimento da ordem judicial, sem multa diária, mas que, se ele for desrespeitado, as astreintes devem ser fixadas em valor expressivo para o multado, sem limite prévio de um teto.

Pôde-se constatar que a existência de um limite prévio (teto), para a multa diária representará não apenas permissão do cálculo custo-benefício para o descumprimento da 
tutela específica da obrigação, mas também retirar a efetividade do instrumento processual capaz de compelir o multado a promover a reparação in natura, que é o grande objetivo do processo ambiental.

\section{REFERÊNCIAS}

ALBERGARIA, Bruno. Direito ambiental e responsabilidade civil das empresas. Belo Horizonte: Fórum, 2009.

ÁVILA, Humberto. Teoria dos princípios. 10. ed. São Paulo: Malheiros, 2009.

BECHARA, Érica. Licenciamento e compensação ambiental na Lei do Sistema Nacional das Unidades de Conservação. São Paulo: Atlas, 2009.

BRASIL. Constituição da República Federativa do Brasil, de 05 out. 1988. Diário Oficial da União, Brasília, 05 out. $1988 . \quad$ Disponível em: <http://www.planalto.gov.br/ccivil_03/constituicao/constituicaocompilado.htm>. Acesso em: 19 jun. 2016.

BRASIL. Lei n ${ }^{\circ}$ 5.869, de 11 jan. 1973. Institui o Código de Processo Civil. Diário Oficial da União, Brasília, 17 jan. 1973. Disponível em: <http://www.planalto.gov.br/ccivil_03/leis/L5869compilada.htm>. Acesso em: 19 jun. 2016.

BRASIL. Lei $n^{\circ}$ 6.938, de 31 ago. 1981. Dispõe sobre a Política Nacional do Meio Ambiente, seus fins e mecanismos de formulação e aplicação, e dá outras providências. Diário Oficial da União, Brasília, 02 set. 1981. Disponível em: <http://www.planalto.gov.br/ccivil_03/LEIS/L6938.htm>. Acesso em: 19 jun. 2016.

BRASIL. Lei $n^{0} 7.347$, de 24 jul. 1985. Disciplina a ação civil pública de responsabilidade por danos causados ao meio-ambiente, ao consumidor, a bens e direitos de valor artístico, estético, histórico, turístico e paisagístico e dá outras providências. Diário Oficial da União, Brasília, 25 jul. $1985 . \quad$ Disponível <http://www.planalto.gov.br/ccivil_03/LEIS/L7347orig.htm>. Acesso em: 19 jun. 2016.

BRASIL. Lei no 8.078, de 11 set. 1990. Dispõe sobre a proteção do consumidor e dá outras providências. Diário Oficial da União, Brasília, 12 set. 1990. Disponível em: <http://www.planalto.gov.br/ccivil_03/Leis/L8078.htm>. Acesso em: 19 jun. 2016.

BRASIL. Lei $n^{\circ}$ 10.406, de 10 jan. 2002. Institui o Código Civil. Diário Oficial da União, Brasília, 11 jan. 2002. Disponível em: <http://www.planalto.gov.br/ccivil_03/leis/2002/L10406.htm>. Acesso em: 19 jun. 2016.

BRASIL. Lei $\mathrm{n}^{\circ} 13.105$, de 16 mar. 2015. Código de Processo Civil. Diário Oficial da União, Brasília, 17 mar. 2015. Disponível em: < http://www.planalto.gov.br/ccivil_03/_ato2015-2018/2015/lei/113105.htm>. Acesso em: 19 jun. 2016. 
BRASIL. Superior Tribunal de Justiça. Quarta Turma. Agravo Regimental no AREsp 697126 SP 2015/0090161-6. Rel. Min. Maria Isabel Gallotti, Brasília, 16 jun. 2015. Diário de Justiça, Brasília, 22 jun. 2015. Disponível em: 〈http://www.stj.jus.br/portal/site/STJ>. Acesso em: 19 jun. 2016.

BRASIL. Superior Tribunal de Justiça. Terceira Turma. Recurso Especial 1185260/GO. Rel. Min. Nancy Andrighi, Brasília, 07 out. 2010. Diário de Justiça, Brasília, 11 nov. 2010. Disponível em: <http://www.stj.jus.br/portal/site/STJ>. Acesso em: 19 jun. 2016.

COELHO, Helena Carvalho. Do direito constitucional ao meio ambiente e desdobramentos principiológicos à hermenêutica (ambiental?). Veredas do Direito: Direito Ambiental e Desenvolvimento Sustentável, Belo Horizonte, v. 11, no 21, p. 53-73, jan./jun. 2014. Disponível em: <http://www.domhelder.edu.br/revista/index.php/veredas/article/view/407>. Acesso em: 19 jun. 2016.

COSTA, Beatriz Souza. Meio ambiente como direito à vida: Brasil, Portugal, Espanha. Belo Horizonte: O Lutador, 2010.

DWORKIN, Ronald. Levando os direitos a sério. Tradução de Nelson Boeira. São Paulo: Martins Fontes, 2002.

FIORILlO, Celso Antônio Pacheco. Curso de direito ambiental brasileiro. 9. ed. São Paulo: Saraiva, 2008.

FRANÇA, Verônica Maria Ramos do Nascimento; VILELA, Bruna Luísa Capellini. Os métodos interpretativos de Ronald Dworkin para solução de conflitos ambientais no ordenamento jurídico brasileiro. In: REIS, Émilien Villas Boas (Org.). Entre a filosofia e o ambiente: bases filosóficas para o Direito Ambiental. Belo Horizonte: 3i editora, 2014. Cap. 6, p- 117-132.

GARCIA, Denise Schmitt Siqueira. Dimensão econômica da sustentabilidade: uma análise com base na economia verde e a teoria do decrescimento. Veredas do Direito: Direito Ambiental e Desenvolvimento Sustentável, Belo Horizonte, v. 13, no 25, p. 133-153, mai. 2016.

Disponível em: <http://www.domhelder.edu.br/revista/index.php/veredas/article/view/487>. Acesso em: 05 set. 2016.

MACHADO, Paulo Affonso Leme. Direito ambiental brasileiro. 18. ed. São Paulo: Malheiros, 2010.

RAMOS, Dempsey. O futuro como fundamento gnoseológico de validade do direito ambiental. Veredas do Direito: Direito Ambiental e Desenvolvimento Sustentável, Belo Horizonte, v. 11, $\mathrm{n}^{\mathrm{0}}$ 21, p. 281-315, jan./jun. 2014. Disponível em: <http://www.domhelder.edu.br/revista/index.php/veredas/article/view/411>. Acesso em: 19 jun. 2016. 
RODRIGUES, Marcelo Abelha. Processo civil ambiental. 2. ed. São Paulo: Revista dos Tribunais, 2010.

SAMPAIO, José Adércio Leite. A constitucionalização dos princípios de Direito ambiental. In: SAMPAIO, José Adércio Leite; WOLD, Chris; NARDY, Afrânio (Org.). Princípios de direito ambiental: na dimensão internacional e comparada. Belo Horizonte: Del Rey, 2003, Cap. 2, p. 45-85.

SÃO PAULO. Tribunal de Justiça. $1^{\text {a }}$ Câmara Reservada ao Meio Ambiente. Apelação. 0149718-53.2009.8.26.0100. Rel. Des. João Negrini Filho, São Paulo, 28 fev. 2013. Diário de Justiça, São Paulo, 01 mar. 2013. Disponível em: <http://www.tjsp.jus.br/>. Acesso em: 19 jun. 2016.

SÃO PAULO. Tribunal de Justiça. 2 $2^{\mathrm{a}}$ Câmara Reservada ao Meio Ambiente. Agravo de Instrumento 2041593-87.2014.8.26.0000. Rel. Des. Paulo Ayrosa, São Paulo, 23 out. 2014. Diário de Justiça, São Paulo, 28 out. 2014. Disponível em: <http://www.tjsp.jus.br/>. Acesso em: 19 jun. 2016.

SILVA, José Afonso da. Direito ambiental constitucional. 10. ed. São Paulo: Malheiros, 2013.

THOMÉ, Romeu. O princípio da vedação de retrocesso socioambiental. Salvador: Jus Podivm, 2014.

VIANNA, José Ricardo Alvarez. Responsabilidade civil por danos ao meio ambiente. Curitiba: Juruá, 2009. 